\title{
In vitro and In vivo Antibacterial and Anti-inflammatory Properties of Linalool
}

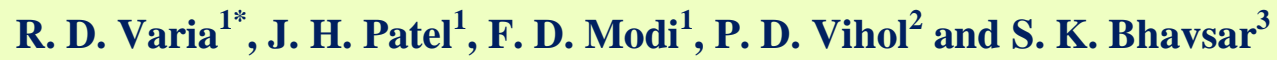 \\ ${ }^{1}$ Department of Pharmacology \& Toxicology, ${ }^{2}$ Department of Pathology, College of \\ Veterinary Science \& Animal Husbandry, Navsari Agricultural University, Navsari - Gujarat \\ (396450), India \\ ${ }^{3}$ Department of Pharmacology \& Toxicology, AAU, Anand, India \\ *Corresponding author
}

\section{A B S T R A C T}

\begin{tabular}{l} 
K e y w o r d s \\
$\begin{array}{l}\text { Linalool, } \\
\text { Antibacterial, Anti- } \\
\text { inflammatory, } \\
\text { Carrageenan, } \\
\text { Lipopolysaccharide, } \\
\text { Rat }\end{array}$ \\
Article Info \\
$\begin{array}{l}\text { Accepted: } \\
\text { 12 August } 2020 \\
\text { Available Online: } \\
\text { 10 September } 2020\end{array}$ \\
\hline
\end{tabular}

\section{Ke y w o r d s}

Linalool, inflammatory, Carrageenan, Lipopolysaccharide,

\section{Introduction}

Since ancient era, Indian people have intellectual knowledge of traditional medicine and were used to treat many acute and chronic diseases in human as well as in animal being. Natural sources like plants, animals, microbes are also of great interest in new drug discovery. Furthermore, India has wide diversity in nature which is beneficial to
The present study was planned to determine in vitro and in vivo antibacterial and antiinflammatory properties of Linalool. In vitro antibacterial activity of Linalool was determined by micro broth dilution technique and MICs were observed as 1.25, 1.25, 1.25, $0.63,1.25,0.63$ and $1.25 \mathrm{mg} / \mathrm{ml}$ against Staphylococcus aureus, Streptococcus pyogenus, Bacillus subtillis, Escherichia coli, Salmonella typhimurium, Pseudomonas aerugonosa and Proteus mirabilis, respectively. In vivo antibacterial efficacy of Linalool was determined in neutropenic rat thigh infection model and significant antibacterial efficacy was observed as compared to growth control with bacterial colony count $4.07 \pm 0.05$ $\log _{10} \mathrm{cfu} / \mathrm{ml}$. In vitro anti-inflammatory activity was tested for their ability to inhibit COX2 enzyme by measuring PGE $_{2}$ level and determination of NO production in LPS treated RAW264.7 macrophage cells. At all concentrations of Linalool (10, 50 and $100 \mu \mathrm{M})$ found to have significant inhibition of $\mathrm{NO}$ and $\mathrm{PGE}_{2}$ production compared with LPS control group. In vivo anti-inflammatory activity of Linalool $(100 \mathrm{mg} / \mathrm{kg})$ was assessed using the carrageenan-induced rat paw edema model at different time intervals following intramuscular injection and observed significant percent inhibition of edema volume compared with carrageenan control group. 
antioxidant and anticancer properties (Kamatou and Viljoen, 2008). Terpenoids are also found in spices and condiments which we are using in our routine life and can be used in primary healthcare. Looking to above facts, present study was planned to evaluate in vitro and in vivo antibacterial and antiinflammatory activities of Linalool.

\section{Materials and Methods}

\section{Animals}

This study was conducted on female albino wistar rats weighing $305 \pm 2.60$ grams and $353 \pm 4.81$ grams for in vivo antiinflammatory and antibacterial protocol, respectively. The experimental protocol was approved by Institutional Animal Ethics Committee (IAEC) of Veterinary College, NAU, Navsari with permission number 057VCN-VPT-2018.

\section{Reagents}

Linalool (97\%), Lambda $(\lambda)$ carrageenan, $\mathrm{N} \omega$-Nitro-L-arginine methyl ester hydrochloride (NAME), Dulbecco's Modified Eagle's Medium - high glucose (DMEM), Meloxicam, Lipopolysaccharide (LPS), Cyclophosphamide, Iodonitrotetrazolium chloride (INT) and 3-(4,5-dimethylthiazol2yl)-2,5-diphenyl-2H-tetrazolium bromide (MTT) were purchased from Sigma-Aldrich, St. Louis, USA.

Indomethacin was obtained from Calbiochem. Dimethylsulfoxide (DMSO) andSodium nitrite were purchased from Merck Specialties Private Limited, Mumbai. Chloramphenicol, Celecoxib, Sulfanilamide, N-(1-Naphthyl) ethylenediaminedihydrochloride (NEDD), Eosin Methylene Blue (EMB) agar, Fetal bovine serum, Brain heart infusion (BHI) broth and antibiotic antimycotic solution 100X liquid were purchased from Himedia
Laboratories Private Limited, Mumbai. Typed bacterial cultures were purchased from National Collection of Industrial Microorganisms (NCIM), Pune and murine macrophage cell line RAW 264.7 was purchased from National Centre for Cell Science (NCCS), Pune. Ethanol was used from store of Veterinary College, NAU, Navsari after triple distillation. HPLC grade de-ionized water was used in all in vitro and in vivo procedures.

Prostaglandin $\mathrm{E}_{2}$ express ELISA kit (Item No. 500141) was purchased from Cayman Chemical Company, Ann Arbor, MI USA.

\section{In vitro antibacterial effect}

Linalool stock $(40 \mathrm{mg} / \mathrm{ml})$ was prepared in 3\% Tween-20. Chloramphenicol stock (250 $\mu \mathrm{g} / \mathrm{ml}$ ) was prepared in sterile water to use as positive control. Bacterial cultures were prepared to Mcfarland 0.5 standard equivalent to $1.5 \times 10^{8} \mathrm{cfu} / \mathrm{ml}$. Final dispensing inoculums were prepared in sterile test tubes by adding $2 \mathrm{ml}$ bacterial suspension $(1.5 \mathrm{x}$ $10^{8} \mathrm{cfu} / \mathrm{ml}$ ) of respective organisms into 198 $\mathrm{ml}$ of sterile broth. Final dispensing inoculums concentration was $1.5 \times 10^{6} \mathrm{cfu} / \mathrm{ml}$.

Minimum inhibitory concentrations (MICs) of Linalool were determined for different gram positive and gram negative organisms like Staphylococcus aureus (ATCC25923), Streptococcus pyogenus (ATCC8668), Bacillus subtillis (ATCC9372), Escherichia coli (ATCC25922), Salmonella typhimurium (ATCC23564), Pseudomonas aerugonosa (ATCC27853) and Proteus mirabilis (NCIM2241) by microbroth dilution technique (Wiegand et al., 2008; Modi et al., 2018). Iodonitrotetrazolium chloride (INT) dye was used to observe visual viability of bacteria. The assay was performed in triplicate. 


\section{In vivo antibacterial efficacy}

In vivo antibacterial efficacy of Linalool was evaluated in neutropenic rat thigh infection model (Zhao et al., 2016). Neutropenic rat model was prepared by injecting cyclophosphamide intraperitoneally in rats on days $1(150 \mathrm{mg} / \mathrm{kg})$ and on day $4(100$ $\mathrm{mg} / \mathrm{kg}$ ). After confirmation of neutropenic condition, rats were infected with $0.2 \mathrm{ml}$ bacterial suspension of Escherichia coli ATCC25922 $\left(1.5 \times 10^{8} \mathrm{cfu} / \mathrm{ml}\right)$ in left thigh on same day. Linalool $(100 \mathrm{mg} / \mathrm{kg})$ which was prepared in DMSO was administered intramuscularly at total injectable volume of $200 \mu \mathrm{l}$ at $2 \mathrm{~h}$ and $8 \mathrm{~h}$ post infection in right thigh (Group-I). Group-II animals were treated with bacterial suspension $(0.2 \mathrm{ml}, \mathrm{IM})$ and Chloramphenicol (50 $\mathrm{mg} / \mathrm{kg}, \quad \mathrm{IM})$ (Positive Control), Group-III animals were treated with bacterial suspension $(0.2 \mathrm{ml}, \mathrm{IM})$ and DMSO (0.2 ml, IM) (Vehicle Control), Group-IV animals were treated with only bacterial suspension (0.2 ml, IM) (Growth Control). After 24 hours, 1 gram thigh muscle samples from infected site were collected following euthanasia under sterile condition. Suitable dilution of samples were inoculated on Eosin Methylene Blue (EMB) agar plates and incubated overnight at $37^{\circ} \mathrm{C}$. Bacterial colonies were enumerated by colony counter and $\log _{10} \mathrm{cfu} / \mathrm{gram}$ was calculated.

\section{In vitro anti-inflammatory effect}

In vitro anti-inflammatory effect of Linalool was evaluated in murine macrophage cell line RAW 264.7 by measuring COX-2 enzyme inhibition via detection of $\mathrm{PGE}_{2}$ concentration and by measuring NO production inhibition. Linalool $(100 \mu \mathrm{M}, 50 \mu \mathrm{M}$ and $10 \mu \mathrm{M})$ was prepared in $0.008 \%$ ethanol in cell culture medium. Cells were grown in DMEM (Dulbecco's Modified Eagle Medium) high glucose supplemented with $10 \%$ foetal bovine serum, $1 \%$ antibiotic antimycotic solution
100X. The cells were transferred in 12 well plate $\left(1 \times 10^{6}\right.$ cells per well) and incubated for 24 hours at $37^{\circ} \mathrm{C}$ and $5 \% \mathrm{CO}_{2}$ in humidified condition. The cells again washed and supplemented with $1600 \mu \mathrm{L}$ fresh cell culture medium and $200 \mu \mathrm{L}$ Linalool in different concentrations $(100 \mu \mathrm{M}, 50 \mu \mathrm{M}$ and $10 \mu \mathrm{M})$ for $\mathrm{NO}$ production inhibition and $\mathrm{PGE}_{2}$ inhibition assay. Positive control wells in NO production inhibition assay includes $1600 \mu \mathrm{L}$ fresh cell culture medium and $200 \mu \mathrm{L} \mathrm{N \omega}$ Nitro-L-arginine methyl ester hydrochloride (NAME, $100 \mu \mathrm{M}$ ) and for $\mathrm{PGE}_{2}$ inhibition assay positive control wells were dispensed with $1600 \mu \mathrm{L}$ cell culture medium and $200 \mu \mathrm{L}$ Celecoxib $(100 \mu \mathrm{M})$. Vehicle control wells were dispensed with $1600 \mu \mathrm{L}$ cell culture medium and $200 \mu \mathrm{L} 0.008 \%$ ethanol and LPS control wells were dispensed with $1800 \mu \mathrm{L}$ cell culture medium. Assay was performed in triplicate for test drugs and standards. All plates were incubated at $37^{\circ} \mathrm{C}$ and $5 \% \mathrm{CO}_{2}$ in humidified condition for 2 hours. Then $200 \mu \mathrm{L}$ LPS $(1 \mu \mathrm{g} / \mathrm{ml})$ was added in all wells and again incubated at $37^{\circ} \mathrm{C}$ and $5 \% \quad \mathrm{CO}_{2}$ in humidified condition for 24 hours. After incubation, supernatant was collected in sterile microcentrifuge tubes individually and centrifuged at $3000 \mathrm{rpm}$ for 5 minutes. Supernatant was collected and divided in two parts: one was used to quantify COX-2 enzyme via measuring $\mathrm{PGE}_{2}$ concentration using Prostaglandin $\mathrm{E}_{2}$ express ELISA kit from Cayman Chemical Company, Ann Arbor, MI USA following procedure as recommended by the manufacturer (Barton et al., 2014) and another part was used to quantify nitrite accumulated in medium as an indicator of NO production using Griess reaction (Choi et al., 2018). Sodium nitrite standard calibration curve $(1.56 \mu \mathrm{M}$ to $50.0 \mu \mathrm{M})$ was prepared to validate the method of estimation and using correlation equation, concentration of $\mathrm{NO}$ was evaluated. Results were expressed as percent inhibition of $\mathrm{NO}$ and $\mathrm{PGE}_{2}$ production in comparison to LPS control. 


\section{Cell viability}

Cell viability was also carried out in test samples by MTT assay (Choi et al., 2018).After sample collection for assay, twenty $\mu \mathrm{L}$ of MTT solution $(5 \mathrm{mg} / \mathrm{ml})$ was added to each well, and the plates were incubated for $4 \mathrm{~h}$ at $37^{\circ} \mathrm{C}$. The supernatants were then collected and the formed formazan crystals in each well were dissolved in $200 \mu \mathrm{L}$ of dimethyl sulfoxide (DMSO) for 30 minutes at $37^{\circ} \mathrm{C}$. The optical density at $570 \mathrm{~nm}$ was read in spectrophotometer. Cell viability percentage was calculated.

\section{In vivo anti-inflammatory efficacy}

The carrageenan-induced rat paw edema model was used with minor modification as described by (Suebsasanaet al., 2009; Modi et al., 2019). Linalool (100 $\mathrm{mg} / \mathrm{kg})$ and Indomethacin $(5 \mathrm{mg} / \mathrm{kg})$ were prepared in DMSO. Experiment animals $(\mathrm{n}=24)$ were divided into 4 groups with 6 animals in each group. A mark on the left hind paw was made in each animal and initial volume was measured by immersing in the plethysmometerpersplex tube. Group-I animals were kept as Carrageenan control. Group-II animals were given DMSO (Vehicle Control), Group-III animals were treated with Indomethacin $(5 \mathrm{mg} / \mathrm{kg} \mathrm{IM})$ and Group-IV animals were treated with Linalool (100 $\mathrm{mg} / \mathrm{kg}$ IM). Lambda carrageenan solution (1\%) prepared in $0.9 \%$ normal saline and 100 $\mu 1$ was injected subcutaneously into sub plantar region of left hind paw. Half an hour before the carrageenan administration, test drug and positive control drug were injected via intramuscular route in respective animal groups. Oedema was measured in paw volume $(\mathrm{ml})$ before carageenan administration and at 1,2,3,4, 5 and $6 \mathrm{~h}$ after carrageenan administration and expressed as percent oedema formation in relation to initial paw volume before carrageenan injection for each animal. The paw volume data for test drug and positive control drug were analyzed and expressed as percent inhibition of oedema formation in comparison to carrageenan control group.

\section{Statistical analysis}

Data are expressed as Mean \pm S.E. The data were analysed using one way ANOVA and significance level was checked at 1 per cent and 5 per cent by Duncan's New Multiple Range Test (DNMRT) using SPSS-20 software.

\section{Results and Discussion}

\section{Antibacterial effect}

Minimum inhibitory concentration of Linalool against Staphylococcus aureus, Streptococcus pyogenus, Bacillus subtillis, Escherichia coli, Salmonella typhimurium, Pseudomonas aerugonosand Proteus mirabilis were observed as $1.25,1.25,1.25$, $0.63,1.25,0.63$ and $1.25 \mathrm{mg} / \mathrm{ml}$ (Table 1). Significant in vivo antibacterial efficacy of Linalool was observed using neutropenic rat thigh infection model with Escherichia coli colony count as $4.07 \pm 0.05 \log _{10} \mathrm{cfu} / \mathrm{ml}$ (Table 2).

\section{Anti-inflammatory Effect}

In present study, percent inhibitions of NO production were measured as $37.47 \pm 3.30 \%$, $55.51 \pm 2.84 \%$ and $63.07 \pm 1.84 \%$ and percent inhibition of $\mathrm{PGE}_{2}$ production observed as $93.31 \pm 0.42 \%, 94.34 \pm 0.89 \%$ and $94.35 \pm 0.29 \%$ at concentrations of 10 , 50 and $100 \mu \mathrm{M}$, respectively with significant difference at all concentrations in comparison to LPS control (Table 3). Cell viability percentages of cells treated Linalool and other standards including LPS control were compared with blank control and found more 
than $96 \%$ viability in all. In present in vivo experiment, percent increase in edema volume $(8.36 \pm 3.94 \%, 36.29 \pm 4.86 \%, 35.22$ $\pm 4.76 \%, 36.04 \pm 4.32 \%, 36.88 \pm 5.34 \%$ and $32.82 \pm 4.88 \%$ ) were significantly lower in comparison with carrageenan control group following administration of Linalool at 1, 2, $3,4,5$, and 6 hours, respectively (Figure 1). In addition, following intramuscular administration of Linalool, significant percent increase in paw volume percent inhibitions were observed from 3 to 6 hours (Table 4).

Table.1 Minimum Inhibitory Concentrations of Linalool against various gram positive and gram negative organisms

\begin{tabular}{|l|c|c|c|c|}
\hline \multicolumn{5}{|c|}{ Minimum Inhibitory Concentrations } \\
\hline \multicolumn{1}{|c|}{ Organism } & $\mathbf{1}$ & $\mathbf{2}$ & $\mathbf{3}$ & Mode \\
\hline Staphylococcus aureus ATCC25923 & 1.25 & 1.25 & 1.25 & 1.25 \\
\hline Streptococcus pyogenes ATCC8668 & 1.25 & 0.63 & 1.25 & 1.25 \\
\hline Bacillus subtilis ATCC9372 & 1.25 & 1.25 & 1.25 & 1.25 \\
\hline Escherichia coli ATCC25922 & 0.63 & 0.63 & 0.63 & 0.63 \\
\hline Salmonella typhimurium ATCC23564 & 1.25 & 1.25 & 1.25 & 1.25 \\
\hline Pseudomonas aeruginosa ATCC27853 & 0.63 & 1.25 & 0.63 & 0.63 \\
\hline Proteus mirabilis NCIM2241 & 1.25 & 1.25 & 1.25 & 1.25 \\
\hline
\end{tabular}

Table. $2 \log _{10} \mathrm{cfu} / \mathrm{ml}$ of Escherichia coli $\left(1.5 \times 10^{8} \mathrm{cfu} / \mathrm{ml}\right)$ in infected thigh samples of rats treated with drugs including control groups $(\mathrm{n}=6)$

\begin{tabular}{|c|c|c|c|c|c|c|c|}
\hline \multirow{3}{*}{$\begin{array}{l}\text { Treatment } \\
\text { groups }\end{array}$} & \multicolumn{6}{|c|}{ Bacterial colony count $\left(\log _{10} \mathrm{cfu} / \mathrm{ml}\right)$} & \multirow[t]{3}{*}{ Mean \pm S.E. } \\
\hline & \multicolumn{6}{|c|}{ Rat number } & \\
\hline & R1 & $\mathbf{R 2}$ & $\mathbf{R 3}$ & R4 & R5 & R6 & \\
\hline Growth control & 5.40 & 5.28 & 5.44 & 5.20 & 5.32 & 5.42 & $5.35 \pm 0.03^{\mathrm{a}}$ \\
\hline Vehicle control & 5.44 & 5.23 & 5.39 & 5.28 & 5.36 & 5.33 & $5.34 \pm 0.03^{\mathrm{a}}$ \\
\hline Chloramphenicol & 4.08 & 3.90 & 4.18 & 3.95 & 4.15 & 4.00 & $4.05 \pm 0.04^{\mathrm{b}}$ \\
\hline Linalool & 4.18 & 3.90 & 4.11 & 4.04 & 4.20 & 3.90 & $4.07 \pm 0.05^{b}$ \\
\hline
\end{tabular}

Means bearing different superscripts between treatment groups differ significantly $(\mathrm{p}<0.01)$

Table.3 In vitro percentage inhibition of $\mathrm{NO}$ and $\mathrm{PGE}_{2}$ production in LPS induced RAW 264.7 cells treated with different concentrations of Linalool

\begin{tabular}{|l|c|c|}
\hline Treatment group & $\begin{array}{c}\text { Percent inhibition }(\boldsymbol{\%}) \mathbf{\pm} \text { S.E. of } \\
\text { NO production }\end{array}$ & $\begin{array}{c}\text { Percent inhibition }(\%) \pm \text { S.E. of } \\
\text { PGE }_{\mathbf{2}} \text { production }\end{array}$ \\
\hline Positive Control & $75.72 \pm 2.52^{\mathrm{b}}$ & $99.72 \pm 0.04^{\mathrm{b}}$ \\
\hline Vehicle Control & $6.52 \pm 1.50^{\mathrm{a}}$ & $3.59 \pm 1.33^{\mathrm{a}}$ \\
\hline Linalool $(\mathbf{1 0} \boldsymbol{\mu M})$ & $37.47 \pm 3.30^{\mathrm{c}}$ & $93.31 \pm 0.42^{\mathrm{c}}$ \\
\hline Linalool $(\mathbf{5 0} \boldsymbol{\mu M})$ & $55.51 \pm 2.84^{\mathrm{d}}$ & $94.34 \pm 0.89^{\mathrm{c}}$ \\
\hline Linalool $(\mathbf{1 0 0} \boldsymbol{\mu M})$ & $63.07 \pm 1.84^{\mathrm{d}}$ & $94.35 \pm 0.29^{\mathrm{c}}$ \\
\hline
\end{tabular}

Means bearing different superscripts between treatment groups differ significantly $(\mathrm{p}<0.01)$ 
Table.4 Percent increase (\%) in paw volumes (Mean \pm S.E.) of carrageenan induced inflammation in rats treated with drugs compared with 0 hour $(n=6)$

\begin{tabular}{|l|c|c|c|c|c|c|}
\hline \multicolumn{1}{|c|}{ Group } & $\mathbf{1 ~ H o u r}$ & $\mathbf{2}$ Hours & $\mathbf{3 ~ H o u r s}$ & $\mathbf{4}$ Hours & $\mathbf{5}$ Hours & $\mathbf{6 ~ H o u r s}$ \\
\hline Carrageenan & $48.18 \pm$ & $60.21 \pm$ & $68.68 \pm$ & $80.57 \pm$ & $88.01 \pm$ & $103.39 \pm$ \\
& $2.62^{\mathrm{aA}}$ & $2.58^{\mathrm{aB}}$ & $3.38^{\mathrm{aB}}$ & $3.04^{\mathrm{aC}}$ & $2.82^{\mathrm{aC}}$ & $3.27^{\mathrm{aD}}$ \\
\hline Vehicle & $34.86 \pm$ & $48.27 \pm$ & $58.83 \pm$ & $70.39 \pm$ & $75.42 \pm$ & $90.60 \pm$ \\
& $4.25^{\mathrm{abA}}$ & $3.55^{\mathrm{abB}}$ & $2.56^{\mathrm{aC}}$ & $4.22^{\mathrm{aD}}$ & $4.00^{\mathrm{aD}}$ & $2.89^{\mathrm{aE}}$ \\
& $(27.65 \pm 8.83$ & $(19.83 \pm$ & $(14.34 \pm$ & $(12.63 \pm$ & $(14.31 \pm$ & $(12.37 \pm$ \\
& $\mathrm{abA})$ & $\left.5.90^{\mathrm{abB}}\right)$ & $\left.3.73^{\mathrm{aC}}\right)$ & $\left.5.24^{\mathrm{aD}}\right)$ & $\left.4.55^{\mathrm{aD}}\right)$ & $\left.2.80^{\mathrm{aE}}\right)$ \\
\hline Indomethacin & $33.09 \pm$ & $31.03 \pm$ & $9.49 \pm$ & $36.42 \pm$ & $44.97 \pm$ & $47.00 \pm$ \\
& $7.39^{\mathrm{bA}}$ & $7.06^{\mathrm{bcAB}}$ & $4.35^{\mathrm{bB}}$ & $9.32^{\mathrm{bcA}}$ & $8.69^{\mathrm{bA}}$ & $8.31^{\mathrm{bA}}$ \\
& $(31.32 \pm 15.3$ & $(48.46 \pm 1.7$ & $(86.18 \pm$ & $(54.80 \pm$ & $(48.90 \pm$ & $(54.54 \pm$ \\
& $\left.5^{\mathrm{bA}}\right)$ & $\left.3^{\mathrm{bcAB}}\right)$ & $\left.6.33^{\mathrm{bB}}\right)$ & $\left.11.57^{\mathrm{bcA}}\right)$ & $\left.9.88^{\mathrm{bA}}\right)$ & $\left.8.03^{\mathrm{bA}}\right)$ \\
\hline Linalool & $8.36 \pm 3.94^{\mathrm{cA}}$ & $36.29 \pm$ & $35.22 \pm$ & $36.04 \pm$ & $36.88 \pm$ & $32.82 \pm$ \\
& $(82.65 \pm 8.18$ & $4.86^{\mathrm{bcB}}$ & $4.76^{\mathrm{cB}}$ & $4.32^{\mathrm{bcB}}$ & $5.34^{\mathrm{bB}}$ & $4.88^{\mathrm{bcB}}$ \\
& $\left.{ }^{\mathrm{bA}}\right)$ & $(39.73 \pm$ & $(48.72 \pm$ & $(55.27 \pm$ & $(58.10 \pm$ & $(68.26 \pm$ \\
& & $\left.7.77^{\mathrm{bcB}}\right)$ & $\left.6.94^{\mathrm{cB}}\right)$ & $\left.5.36^{\mathrm{bcB}}\right)$ & $\left.6.07^{\mathrm{bB}}\right)$ & $\left.4.72^{\mathrm{bcB}}\right)$ \\
\hline
\end{tabular}

Figures in parenthesis shows percent inhibition $(\%) \pm$ S.E. compared with carrageenan control Means bearing different superscripts in small letters between treatment groups and in capital letters within groups differ significantly $(\mathrm{p}<0.01)$

Figure.1 Percent increase (\%) in paw volumes (Mean \pm S.E.) of carrageenan induced inflammation in rats treated with drugs compared with 0 hour $(n=6)$

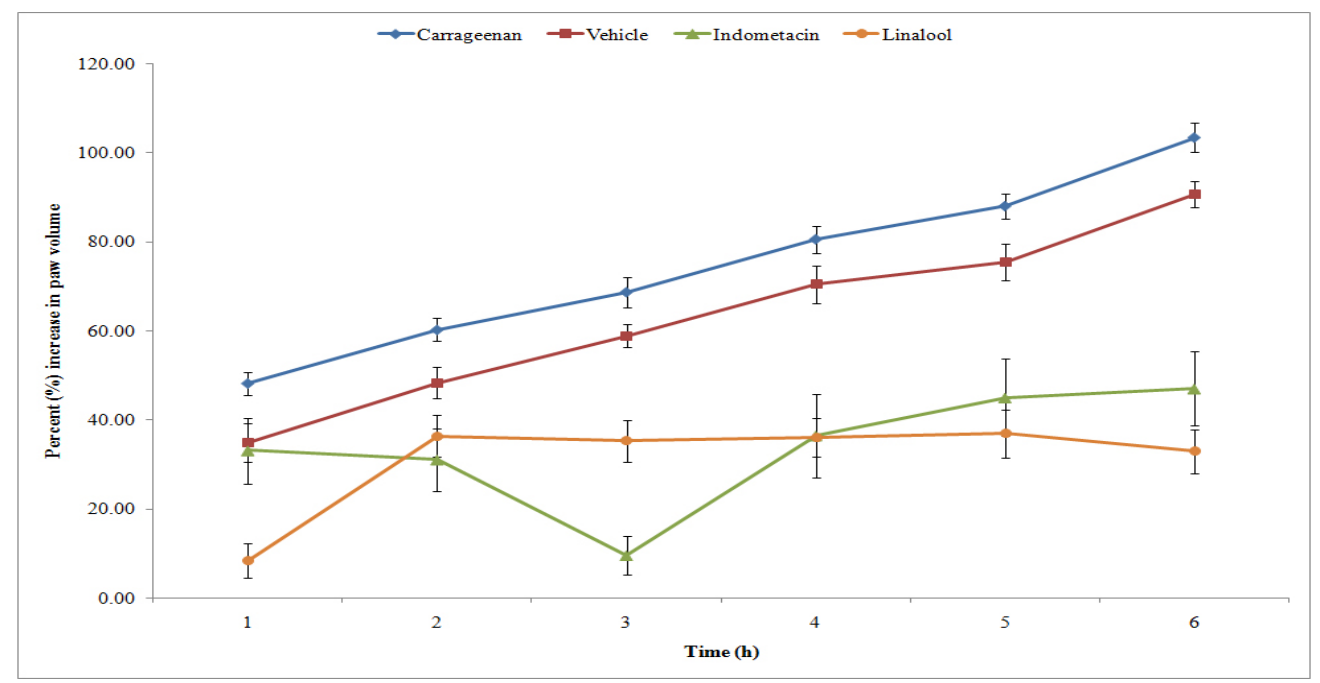

Results of present in vitro antibacterial study are in agreement with MICs of Linalool were observed by other researchers as $1.024 \mathrm{mg} / \mathrm{ml}$ against Staphylococcus aureus and Pseudomonas aerugonosa (Silva et al., 2015) and against Escherichia coli and Staphylococcus aureus as $0.77 \mathrm{mg} / \mathrm{ml}$ and
$1.54 \mathrm{mg} / \mathrm{ml}$, respectively (Jabir et al., 2018). In contrast to present study, lower MICs were observed as 5.0, 4.0, 6.0, 5.0, 7.0 and 6.0 $\mu \mathrm{g} / \mathrm{ml}$ against Staphylococcus aureus, Bacillus subtillis, Escherichia coli, Salmonella typhimurium, Pseudomonas aerugonosa and Proteus mirabilis, 
respectively (Sokovic et al., 2010). Similarly, Dumanet al., (2010) also observed lower MICs as $0.7,0.9$ and $0.7 \mu \mathrm{g} / \mathrm{ml}$ against Pseudomonas aerugonosa, Escherichia coli and Staphylococcus aureus, respectively. Furthermore, in present study statistically significant in vivo antibacterial efficacy of Linalool was observed as compared to growth control in neutropenic rat thigh infection (Escherichia coli) model with bacterial colony count $4.07 \pm 0.05 \log _{10} \mathrm{cfu} / \mathrm{ml}$ which was in agreement with present in vitro observations.

Statistically significant and dose dependent percent inhibitions of $\mathrm{NO}$ production was observed with Linalool(10, 50 and $100 \mu \mathrm{M})$ in present study and significant percent inhibition of $\mathrm{PGE}_{2}$ production observed at all dose level compared to LPS control. The results observed by other researchers supported results of present study like Peana et al., (2006) examined the effect of Linalool $(0.1 \mu \mathrm{M}, \quad 10 \mu \mathrm{M}$ and $1000 \mu \mathrm{M})$ in lipopolysaccharide (LPS) induced macrophages cell line J774.A1 and found significant reduction of $\mathrm{NO}$ and $\mathrm{PGE}_{2}$ production in concentration dependent manner; Li et al., (2015) observed significant and dose dependent inhibition of $\mathrm{NO}$ and $\mathrm{PGE}_{2}$ levels in LPS induced BV2 microglia cells following treatment of Linalool (162, 324, $648 \mu \mathrm{M}$ ) and Kim et al., (2009) evaluated the anti-inflammatory effect of Linalool which is the main content of Illicium anisatum extract $(25,50$ and $100 \mathrm{mg} / \mathrm{ml})$ in RAW 264.7 macrophage cells and found dose dependent reduction of nitrite and $\mathrm{PGE}_{2}$ production. In present in vivo experiment, significant percent inhibitions of carrageenan induced inflammation were observed following single intramuscular administration of Linalool in comparison with carrageenan control group up to 6 hours. The results of present study are in agreement with percent inhibition observed with Linalool $(75 \mathrm{mg} / \mathrm{kg})$ treatment as $38 \%$ and $34 \%$ at 3 and 5 hours after carrageenan administration, respectively (Peana et al., 2002) and percent inhibition of paw edema was observed as $43 \pm 9 \%$ and 66 $\pm 11 \%$ at 4 hours following intraperitoneal administration of Linalool at doses of 50 and $200 \mathrm{mg} / \mathrm{kg}$, respectively in mice (Batista et al., 2010).

In conclusion the linalool possessed in vitro antibacterial activity against various gram positive and gram negative organisms with MIC values ranging from 0.63 to $1.25 \mathrm{mg} / \mathrm{ml}$. Concurrent, in vivo antibacterial efficacy of Linalool was observed in neutropenic rat thigh infection model. Significant decreased $\mathrm{NO}$ and $\mathrm{PGE}_{2}$ levels in LPS induced RAW 264.7 cells treated with different concentrations of Linalool and significant percent inhibition of carrageenan induced rat paw oedema was noticed following single intramuscular administration of Linalool at dose of $100 \mathrm{mg} / \mathrm{kg}$.

\section{Acknowledgement}

I wish to express my gratitude and appreciation to authorities of Veterinary College, Navsari Agricultural University, Navsari, Gujarat for providing me the opportunity and facilities to carryout research work.

\section{Conflict of interest statement}

Authors declare that they have no conflict of interest.

\section{References}

Barton, M.H., Paske, E., Norton, N., King, D., Giguere, S. and Budsberg S. 2014. Efficacy of cyclooxygenase inhibition by two commercially available firocoxib products in horses. Equine Vet J. 46(1): 75-75. 
Doi:10.1111/evj.12095

Batista, P.A., Werner, M.F.P., Oliveira, E.C., Burgos, L., Pereira, P., Brum, L.F.S., Story, G.M. and Santos, A.R.S. 2010. The antinociceptive effect of (-)Linalool in models of chronic inflammatory and neuropathic hypersensitivity in mice. The J. of Pain. 11(11): 1222-1229.

Choi, C.W., Shin, J.Y., Seo, C., Hong, S.S., Ahn, E.K., Jung, Y.H. and Oh, J.S. 2018.In vitro anti-inflammatory activity of the components of Amomumtsao-ko in murine macrophage RAW 264.7 cells.Afr. J. Tradit. Complement. Altern. Med. 15(2): 26-34.

Duman, A.D., Telci, I., Dayisoylu, K.S., Digrak, M., Demirtas, I. and Almae, M.H. 2010. Evaluation of bioactivity of Linalool-rich essential oils from Ocimum basilucum and Coriandrum sativum varieties. Nat. Prod. Commun. 5(6): 969-974.

Jabir, M.S., Taha, A.A. and Sahib, U.I. 2018.Linalool loaded on glutathionemodified gold nanoparticles: A drug delivery system for a successful antimicrobial therapy. Artif. Cells. Nanomed. Biotechnol. 46(2): 345-355.

Kamatou, G.P.P. and Viljoen, A.M. 2008. Linalool - A review of a biologically active compound of commercial importance. Nat. Prod. Commun. 3(7): 1183-1192.

Kim, J.Y., Kim, S.S., Oh, T.H., Baik, J.S., Song, G., Lee, N.H. and Hyun, C.G. 2009. Chemical composition, antioxidant, anti-elastase, and antiinflammatory activities of Illicium anisatum essential oil. Acta Pharm. 59(3): 289-300.

Li, Y., Lv, O., Zhou, F., Li, Q., Wu, Z. and Zheng, Y. 2015. Linalool inhibits LPSinduced inflammation in BV2 microglia cells by activating $\mathrm{Nrf} 2$.
Neurochem Res. 40(7): 1520-1525.

DOI: 10.1007/s11064-015-1629-7

Modi F.D., Bhavsar S.K., Patel J.H., Varia R.D., Modi L.C. and Kale N. 2018.Evaluation of Pharmacokinetics, Antibacterial and Anti-Inflammatory Activities of Chrysin in Rat. Int.J.Curr.Microbiol.App.Sci. $\quad$ 7(9): 1494-1503.

Modi F.D., Bhavsar S.K., Patel J.H., Varia R.D., Modi L.C., Modi M. and Kale N. 2019. Pharmacokinetic profile of rutin after intramuscular administration in rats favoursitsin vivo anti-inflammatory activity in carrageenan-induced rodent model of inflammation. Annals of Phytomedicine. 8(1): 185-192.

Peana, A.T., D'Aquila, P.S., Panin, F., Serra, G., Pippia, P. and Maretti, M.D.L. 2002. Anti-inflammatory activity of Linalool and linalyl acetate constituents of essential oils. Phytomedicine. 9(8): 721-726.

Peana, A.T., Marzocco, S., Popolo, A. and Pinto, A. 2006. (-)-Linalool inhibits in vitro NO formation: Probable involvement in the antinociceptive activity of this monoterpene compound. Life Sciences. 78(7): 719723.

Perveen, S. 2018. Introductory Chapter: Terpenes and Terpenoids. Open access peer-reviewed chapter. http://dx.doi.org/10.5772/intechopen.7 9683

Silva, V.A., Sousa, J.P., Guerra, F.Q.S., Pessoa, H.L.F., Freitas, A.F.R., Alves, L.B.N. and Lima, E.O. 2015. Antibacterial activity of Ocimum basilicum essential oil and Linalool on bacterial isolates of clinical importance. Int. J. Pharmacogn. Phytochem. Res. 7(6): 1066-1071.

Sokovic, M., Glamoclija, J., Marin, P.D., Brkic, D. and van Griensven, L.J.L.D. 2010. Antibacterial effects of the 
essential oils of commonly consumed medicinal herbs using an in vitro model. Molecules. 15(11): 7532-7546.

Suebsasana, S., Pongnaratorn, P., Sattayasai, J., Arkaravichien, T., Tiamkao, S. and Aromdee, C. 2009.Analgesic, antipyretic, anti-Inflammatory and toxic effects of andrographolide derivatives in experimental animals. Arch. Pharm. Res. 32(9): 1191-1200.

Wiegand, I., Hilpert, K. and Hancock, R.E.W. 2008.Agar and broth dilution methods to determine the minimal inhibitory concentration (MIC) of antimicrobial substances. Nature protocols. 3(2): 163-175.

Zhao, M., Lepak, A.J. and Andes, D.R. 2016. Animal models in the pharmacokinetic/pharmacodynamics evaluation of antimicrobial agents. Bioorgan. Med. Chem. 24(24): 63906400 .

\section{How to cite this article:}

Varia, R. D., J. H. Patel, F. D. Modi, P. D. Vihol and Bhavsar, S. K. 2020. In vitro and In vivo Antibacterial and Anti-inflammatory Properties of Linalool. Int.J.Curr.Microbiol.App.Sci. 9(09): 1481-1489. doi: https://doi.org/10.20546/ijcmas.2020.909.187 